\title{
A new microenvironment for the formation of clay minerals: the example of authigenic halloysite- $7 \AA$ and gibbsite in a stalactite from Agios Georgios Cave, Kilkis, north Greece
}

\author{
Elena Ifandi ${ }^{1 *}$, Basilios Tsikouras ${ }^{1,2}$, Dimitrios Papoulis ${ }^{1}$, Konstantin Hatzipanagiotou ${ }^{1}$, \\ and Aspasia Antonelou ${ }^{3,4}$ \\ ${ }^{1}$ University of Patras, Department of Geology, Section of Earth Materials, 26500 Patras, Greece \\ ${ }^{2}$ Universiti Brunei Darussalam, Physical and Geological Sciences, Jalan Tungku Link, BE1410 Gadong, Bandar Seri Begawan, Brunei Darussalam \\ ${ }^{3}$ Foundation for Research and Technology Hellas, Institute of Chemical Engineering Sciences (FORTH/ICE-HT), P.O. Box 1414, 26504 Patras, Greece \\ ${ }^{4}$ University of Patras, Department of Materials Science, 26500 Patras, Greece
}

\begin{abstract}
An unusual authigenic origin for halloysite and gibbsite is reported in a stalactite from Agios Georgios Cave, Kilkis. This speleothem includes mostly pure calcite whereas minor areas of Mg-rich calcite and scarce dolomite are present in four growth phases. Abundant pores are created due to imperfect coalescence of the calcite crystals. Several of them contain detrital muscovite, which was presumably transferred from the dripping water, during the formation of speleothem and has been variably altered to halloysite. Several pores in the stalactite contain different mineral assemblages that we interpret as in situ: halloysite- $7 \AA$, halloysite + silica, gibbsite + silica and gibbsite. The breakdown of the muscovite and the formation of halloysite require acidic conditions, which we suggest to have been established by potassium solubilising microorganisms. The silica minerals include spheroidal assemblages or needlelike and blade-like quartz and can be explained by further dissolution of halloysite, under the same acidic conditions in the presence of microorganisms. In our model, the precipitation of gibbsite is the result of direct formation from muscovite, promoted from abundant and undisturbed water percolation, at moderately low $\mathrm{pH}$, also induced by the presence of bacteria. Given that microbial activities promote: (1) breakdown of muscovite and formation of halloysite, silica, and gibbsite, and (2) formation of Mg-calcite and dolomite after calcite, then it is likely that two or more different microbial communities may exist in the same speleothem. The first creates mild acidic conditions, aiming at the decomposition of muscovite in the microenvironment of the pores antagonising the second that produces alkaline microregimes and the local precipitation of Mg-rich carbonate minerals.
\end{abstract}

Keywords: $\quad$ stalactite; muscovite; halloysite; gibbsite; microorganisms

Received 15 April 2015; Revised 31 August 2015; Accepted 31 August 2015

Citation: Ifandi E., Tsikouras B., Papoulis D., Hatzipanagiotou K. and Antonelou A., 2015. A new microenvironment for the formation of clay minerals: the example of authigenic halloysite and gibbsite in a stalactite from Agios Georgios Cave, Kilkis, north Greece. International Journal of Speleology, 44 (3), 327-340. Tampa, FL (USA) ISSN 0392-6672

http://dx.doi.org/10.5038/1827-806X.44.3.9

\section{INTRODUCTION}

Speleothems diachronically attract the attention of cave researchers because the investigation of their complex formation provides significant information regarding the development of their host caves. In addition, speleothems are thought to be important paleoclimatic and environmental archives on Earth. However, little research has been done on the description of petrographic characteristics and fabrics of speleothems in Greek caves (e.g. Antonelou et al., 2010; Ifandi et al., 2013). Early research of speleothems was focused primarily on the inorganic processes of calcite precipitation (Kendall \& Broughton, 1978; Broughton, 1983), but today the significant role of microorganisms (fungi, algae, bacteria and microbes) is stressed, hence comprising an important modern topic (e.g. Northup \& Lavoie, 2001; Baskar et al., 2005, 2006; Mulec et al., 2007; Jones, 2010, 2011; Rusznyák et al., 2012; Pacton et al., 2013). Microbes are now recognised as direct and/or indirect contributors to the formation of both constructive and destructive textures (summarised in Pacton et al., 2013) in speleothems. The first includes 
calcification, trapping and binding of microbially precipitated minerals whereas the latter comprises microbial corrosion or dissolution of minerals via mechanical attack, biosecretions, and production of acidic fluids. Silicate minerals such as quartz, micas and clay minerals are observed as detrital compounds in speleothems and although they are not "authentic" cave minerals (Hill \& Forti, 1997), they potentially affect any biogeochemical processes taking place after deposition of the detritus. The interaction between mineral surfaces and microbes is a popular research topic, and many researchers are dedicated to explain the mechanisms for the development of the commonest microbially affected minerals in sedimentary rocks like limestones and sandstones (for a detailed review see Northup \& Lavoie, 2001).

To our knowledge, there are very few papers referring to an authigenic production of clay minerals and silicates in carbonate speleothems (e.g. Polyak \& Güven, 2000, 2004; Onac \& Forti, 2011). This paper aims to investigate and describe in detail, the uncommon process of forming silicates in carbonate speleothems through the study of a speleothem from Agios Georgios Cave in Kilkis, Greece. Here we highlight the potential importance of microorganisms in a new environment of mineralisation.

\section{DESCRIPTION OF THE CAVE}

Agios Georgios Cave is located to the SW of Agios Georgios hill, in Kilkis - a town in northern Greece (Fig. 1). The broader, Kilkis valley area is covered by Upper Pleistocene sediments and belongs to the Deve Koran-Doubia subzone of the Circum-Rhodope geotectonic zone (Kauffman et al., 1976). The carbonate system, where the karstification took place, consists of Middle to Upper Triassic limestones (Kockel \& Ioannides, 1979). The fissure-like development of the initial water passages of the cave follows either a N-S or an E-W direction, according to the tectonic stresses during uplift of the region. Agios Georgios Cave is a special karst type, formed by hot hydrothermal water prior to uplift of the host rock (Makridis et al., 2013). Despite its small size (with over $500 \mathrm{~m}$ surveyed passageways, a total surface of around $1000 \mathrm{~m}^{2}$ and a touristic pathway of approximately $250 \mathrm{~m}$; Fig. 2), it contains a large variety of speleothems, developed in two floors. The upper floor is mostly decorated with stalactites and stalagmites, having reddish to dark brown appearance. The lower floor is moreover decorated with a variety of subaqueous coralloids (calcite popcorn) apparently due to the fact that it remained flooded for longer periods.

A significant Pleistocene fauna of mammals has been discovered in the cave (Tsoukala, 1992; Makridis et al., 2013) and isotopic results from a stalactite in the cave provide evidence for alternations of glacial and interglacial periods during the Middle Pleistocene (Antonelou, 2007; Dotsika et al., 2010). Study of the petrographic fabrics, as well as microanalytical data of the carbonate phases in speleothems of the cave are consistent with this interpretation (Antonelou et al., 2010).

\section{METHODS}

A stalactite $18.1 \mathrm{~cm}$ long and $5.6 \mathrm{~cm}$ wide was sampled and cut along its growth axis (Fig. 3). The internal surface of the stalactite was used to prepare a series of polished-thin sections for petrographic study under a Leica SM-LUX POL ORTHOPLAN polarising microscope, equipped with a digital camera and the relevant software (Progress Capture) at the Research Laboratory of Minerals and Rocks, Department of Geology, University of Patras. Representative polished-thin sections were further studied in a field emission scanning electron microscope (FESEM) Zeiss Supra 35VP, equipped with an EDS, at FORTH/ICE-

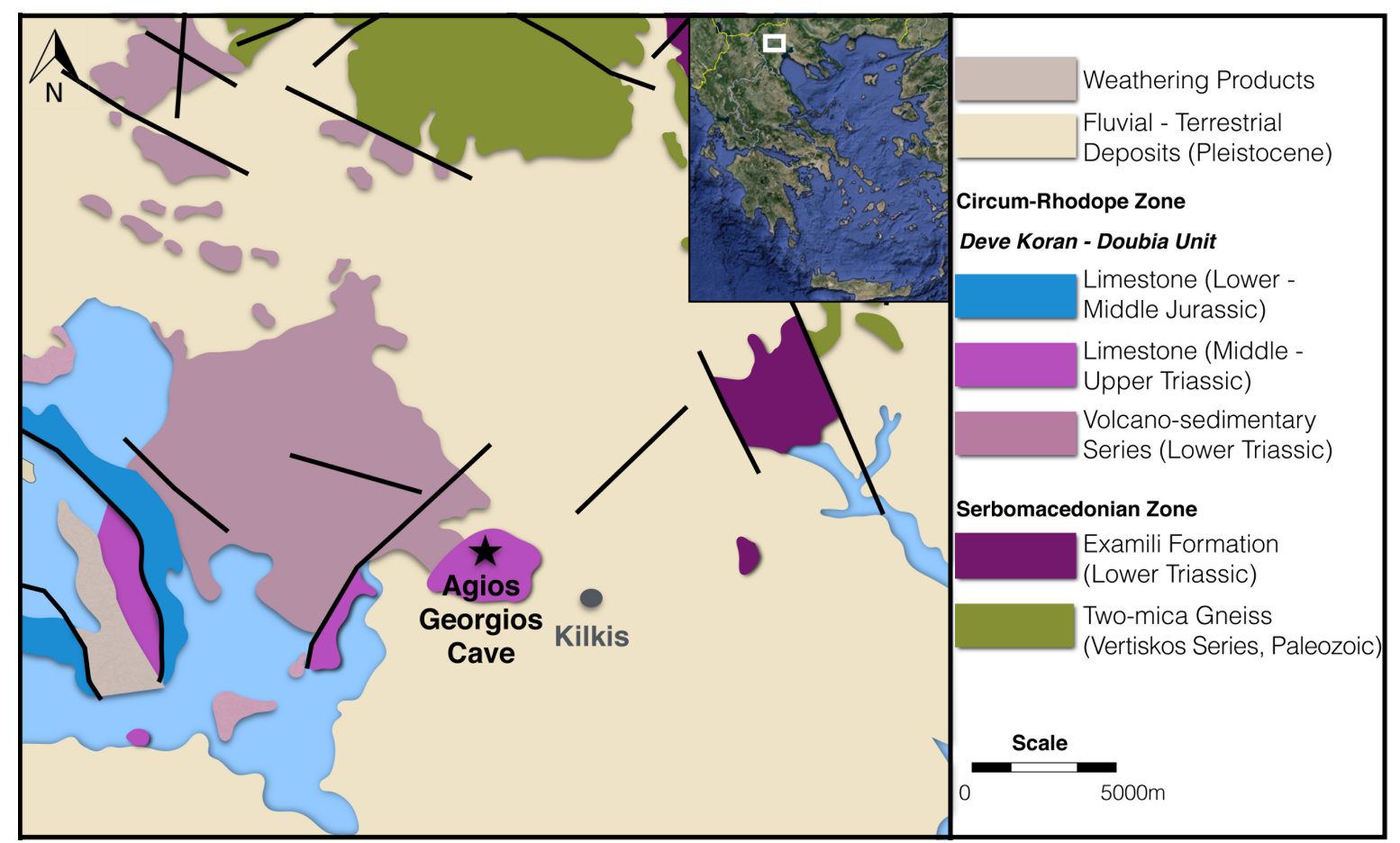

Fig. 1. Simplified geological map of Kilkis showing the position of the Agios Georgios cave (modified after Kockel \& loannides, 1979). 


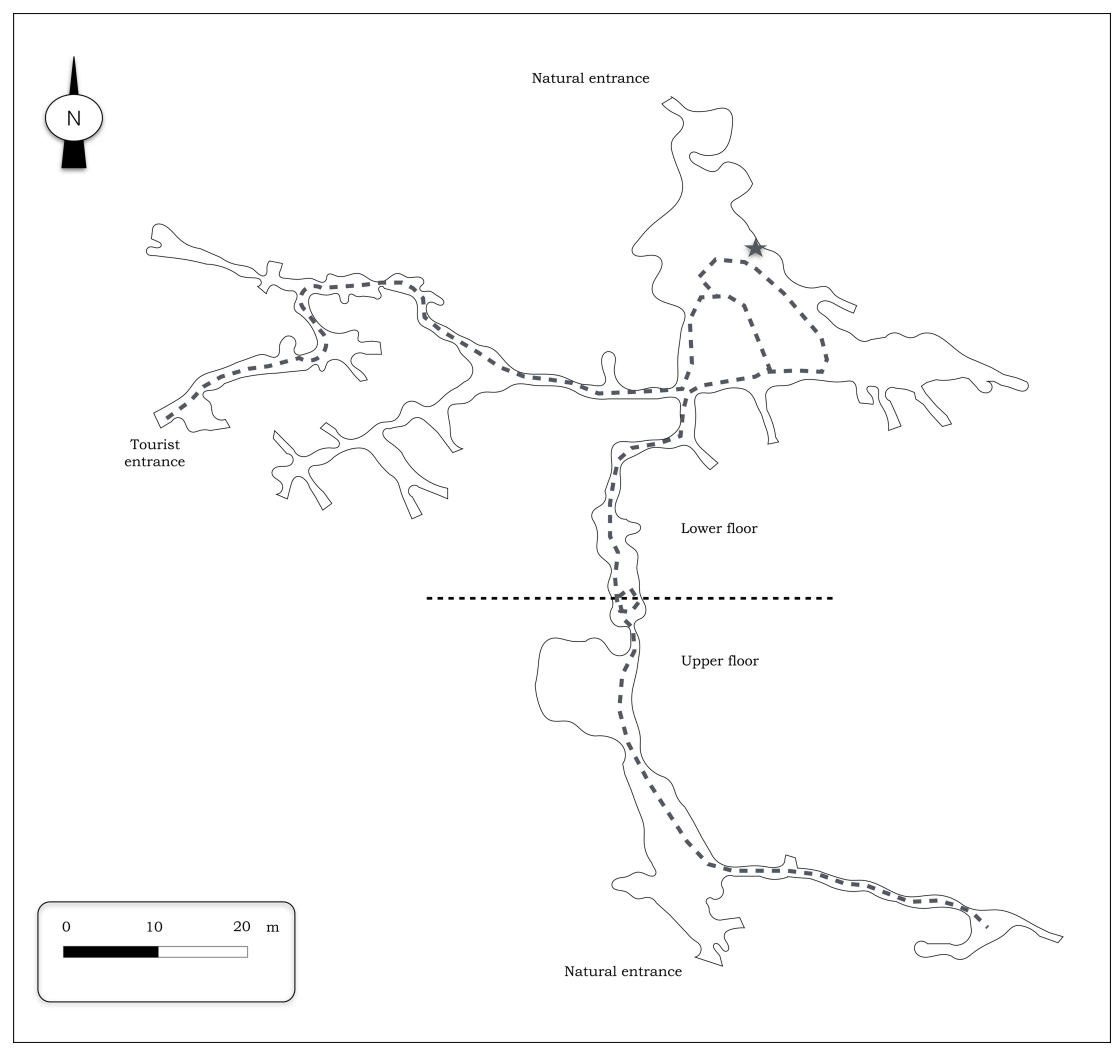

Fig. 2. Simplified map of the Agios Georgios Cave (mapped by the Hellenic Speleological Society). The star indicates the sampling location and the grey dashed line is the tourist path.

\section{PETROGRAPHIC DESCRIPTION}

The stalactite has a hollow soda straw along its growth axis with a diameter ranging between approximately $5 \mathrm{~mm}$ and $7 \mathrm{~mm}$. Four growth phases are observed and their description below follows an outwards direction from the center of the stalactite as expected. The initial soda straw channel is partially filled by sparry calcite (Fig. 4A), and in places, by syntaxial crystals of trigonal calcite that give rise to palisade calcite fabric, which occlude it, leaving local openings up to $0.2 \mathrm{~mm}$ wide. Imperfect coalescence of the crystallites (term after Frisia et al., 2000), is commonly imprinted on the intercrystalline porosity observed. Sparry calcite, which tends to develop into larger columnar crystals, surrounds the central growth axis. Along this direction, spots with radial development of fibrous to micritic calcite show a bulbar appearance (Fig. 4B). These formations are rich in inclusions of type 5 (nomenclature of inclusion types hereafter, after Kendal \& Broughton, 1978), with the characteristic pseudopleochroic calcite and seem to fill

HT, University of Patras, using an accelerating voltage of $30 \mathrm{kV}$. Electron microanalyses were carried out at pre-existing rounded pores. Some of these bulbous formations are terminated by inclusion-rich zones; the Laboratory of Electron Microscopy and Microanalysis, University of Patras, using a Jeol JSM-6300 Scanning Electron Microscope (SEM), equipped with EDS and WDS and a THETA software. Operating conditions were $15 \mathrm{kV}$ accelerating voltage and $3.3 \mathrm{nA}$ beam current. A Transmission Electron Microscope (TEM) with an accelerating voltage of $200 \mathrm{kV}$ was employed for the determination of crystal structures in a carefully hand - milled sample of the stalactite, at the Laboratory of Electron Microscopy and Microanalysis, University of Patras. The sample was studied using bright field images collecting high resolution images for the identification of the crystal phases. Lattice spacings were measured using ImageJ $1.4 \mathrm{v}$ software and PDF library data from EVA v.12 software was used for the identification of the minerals. Finally, X-Ray Diffraction (XRD) was used as an auxiliary method for the determination of clay minerals, using a Bruker D8 Advance diffractometer equipped with a LynxEye ${ }^{\circledR}$ detector, at a $3-70^{\circ} 2 \theta$ range, with a scanning step rate of $0.015^{\circ}$ and 0.2 seconds time per step. The diffractograms were evaluated using the EVA v.12 software, at the Research Laboratory of Minerals and Rocks, Department of Geology, University of Patras.

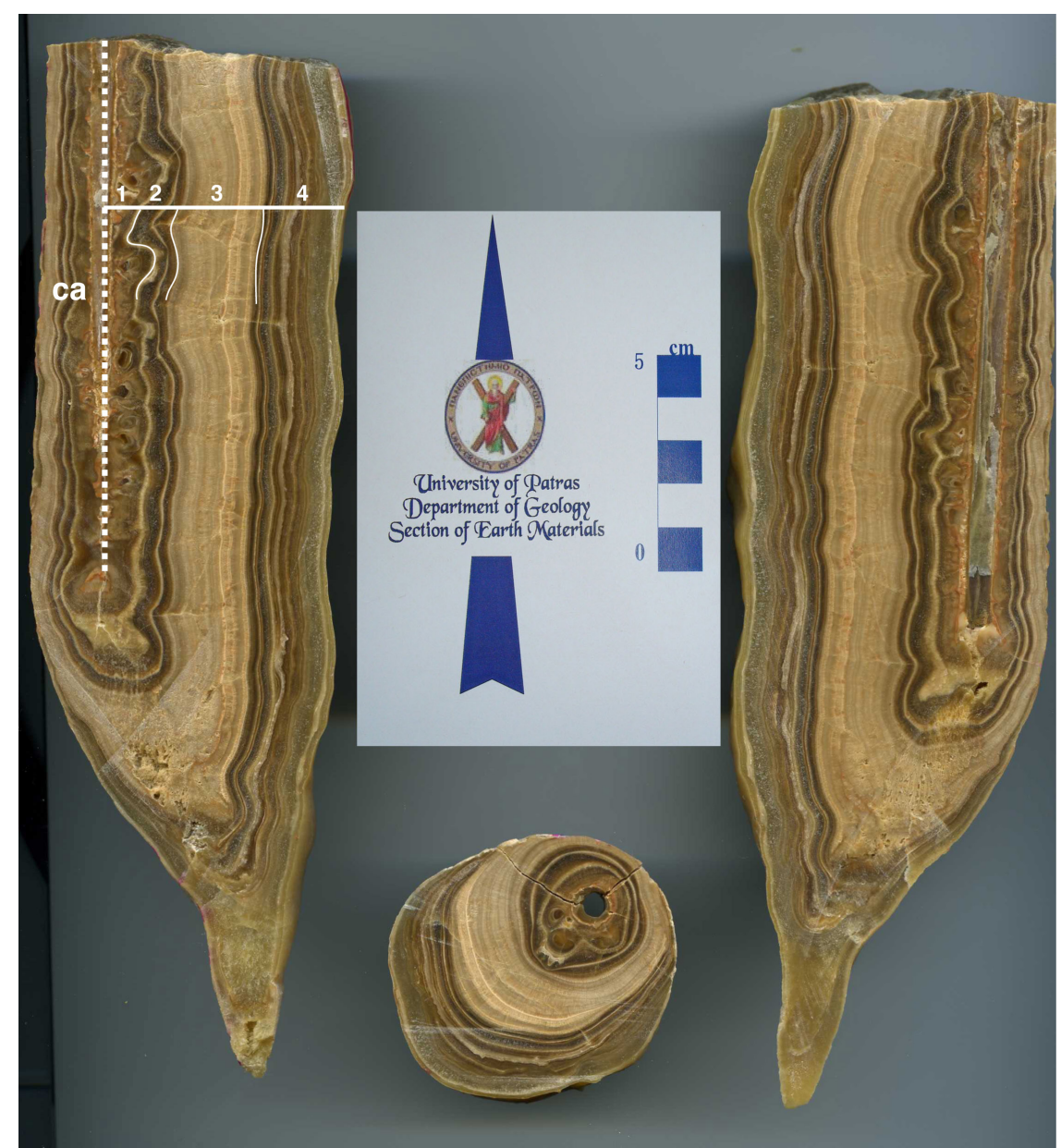

Fig. 3. The stalactite sample cut parallel and perpendicular to its central growth axis (ca) that coincides with its soda straw precursor. Numbers indicate the four growth phases that were recognised. Note that phases 1 and 2 are separated by a growth hiatus. 
typically columnar crystals develop on these zones (Fig. 4B). The spheroidal geometry of the abovementioned formations, leads to the development of columnar crystals with competitive boundaries, which form an extended growth layer along with sparry calcite. Successive inclusion-rich layers of type 2, which are interrupted by a growth hiatus, mark the end of the first growth period of the speleothem (Figs. 3 and 4C).

The second phase starts with inclusion-rich layers, identical with the ones observed at the end of phase 1 (Fig. 4C). Large columnar crystals grow directly on them. Alternations of columnar calcite grown on inclusion-rich layers are observed throughout the second growth phase (Fig. 4C). This fact indicates that these layers comprise a favourable basement for the formation of columnar crystals. A short zone of sparry calcite marks the end of the second phase.

In contrast with the previous phases, clear textural features are absent in the third phase, which instead shows a "chaotic" appearance of calcite (Fig. 4D). Micrite to microsparry calcite sublayers, with diffusion boundaries, are rich in inclusions of type 3. Micritic calcite along with abundant clay minerals, have a uniform pseudopleochroism.
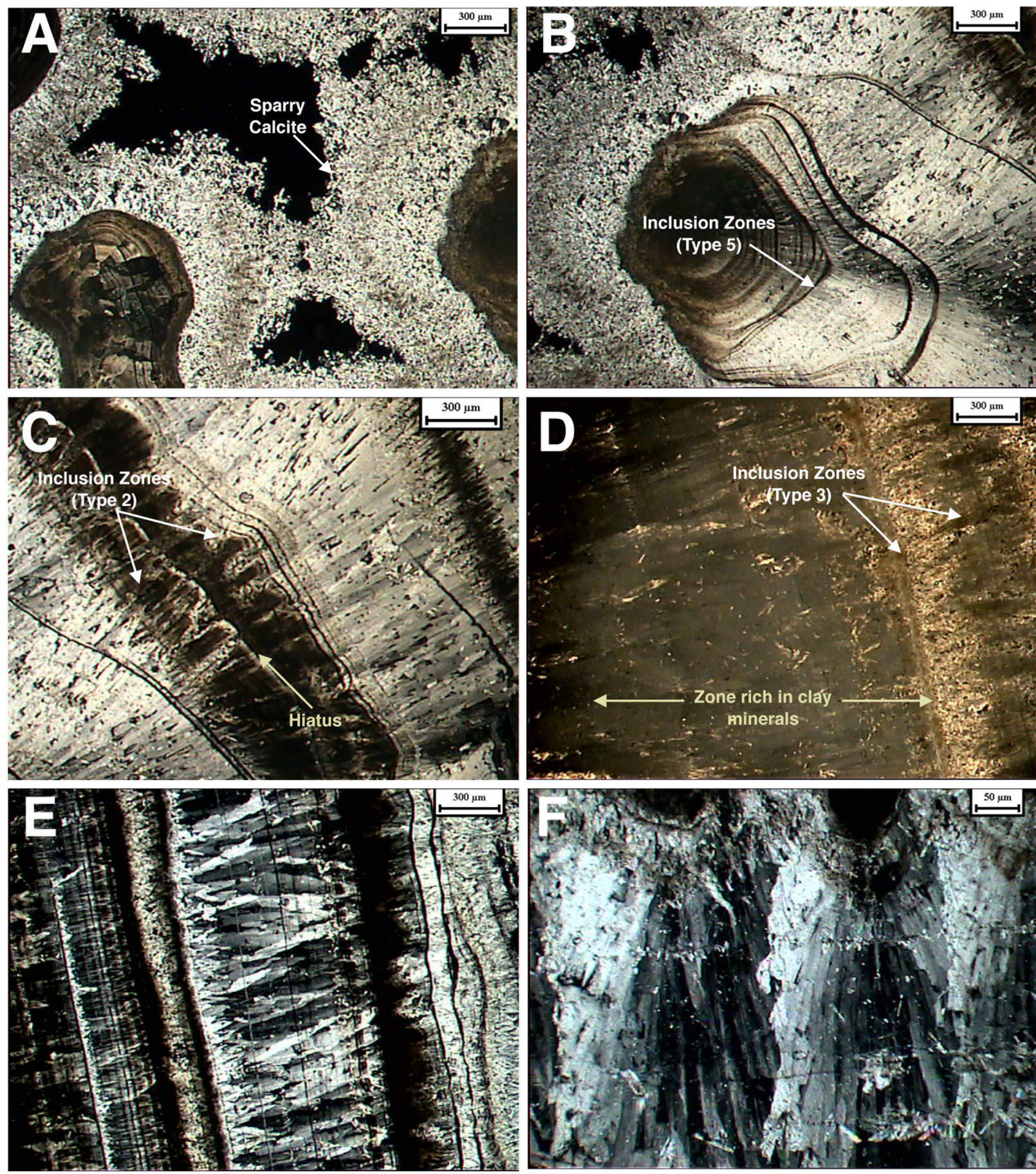

Fig. 4. Photomicrographs of representative thin sections from the stalactite: A) Sparry calcite crystals partially filling the central soda straw precursor; B) A bulbous formation of pseudopleochroic calcite with rounded pores with impurities that form type 5 inclusion rich zones occurring in phase 1; columnar calcite grows on the these inclusion-rich zones (lower right and right); C) Columnar calcite layers of phase 1 (lower left) are terminated by a dark inclusion-rich layer of type 2. A hiatus marks the end of phase 1 and phase 2 starts with a similar inclusion-rich layer succeeded by alternations of columnar calcite; more inclusion-rich layers (upper right) alternate with columnar calcite in this phase; D) Micritic calcite rich in inclusions of type 3 and abundant clay minerals in phase 3; E) Multiple alternations of fibrous carbonate crystals, which are seeded on inclusion-rich layers, subsequently coalesce to form columnar calcite crystals in phase 4; F) Interwoven texture of fibrous calcite crystals occurring in phase 4 of the stalactite. 
The last layer contains multiple alternations of columnar and micritic calcite sublayers grown on inclusion rich layers. Clearly, the formation of the columnar crystals starts after coalescence of smaller fibrous subcrystals, which are seeded directly on the inclusion-rich layers (Fig. 4E). Competitive growth phenomena are also observed creating an interwoven fabric (Fig. 4F), showing that the non syntaxial (to the general growth direction of the stalactite) fibrous calcite is not able to form composite crystals.

\section{SCANNING ELECTRON MICROSCOPY OBSERVATIONS}

Under SEM, using EDX analysis in polished-thin sections, calcite is identified as the dominant mineral phase, coexisting with lesser $\mathrm{Mg}$-rich calcite and scarce dolomite (Figs. 5A, B; Table 1). The columnar calcite, appears either as homogeneous rhombohedral crystals, or as composite crystals comprised of abundant fibrous subcrystals. When columnar crystals show syntaxial arrangement in space, their imperfect coalescence creates linear inclusions, whereas when they are arranged at variable orientations, then trigonal pores are created. Columnar calcite layers are often interrupted by the formation of micritic and minimicritic calcite (terminology after Folk, 1974). This microcrystalline calcite tends to cover the faces and interrupts the growth of the columnar crystals (Fig. 6A), which frequently show spiky surfaces (Fig. 6B; according to Folk et al., 1985). Minimicrite also forms net textures in pockets of dissolved calcite (Figs. 6C and D) and tends to cover elongated and curved structures, which in literature are considered as calcified microorganisms (e.g. Jones, 2010). Irregular or linear distribution of bores are observed on larger calcite surfaces (Figs. 6C, E and F), which are considered as a typical structure resulting from microbial activity (Jones, 2012).

Few larger irregular pores, compared to the relatively smaller linear and trigonal ones, are commonly filled with detrital muscovite which is usually fractured, forming subhedral to anhedral grains, up to approximately $10 \mu \mathrm{m}$ in size (Figs. 7A, B and C); its identification was based on the crystal habit of the crystals and electron microanalysis (Table 2). In
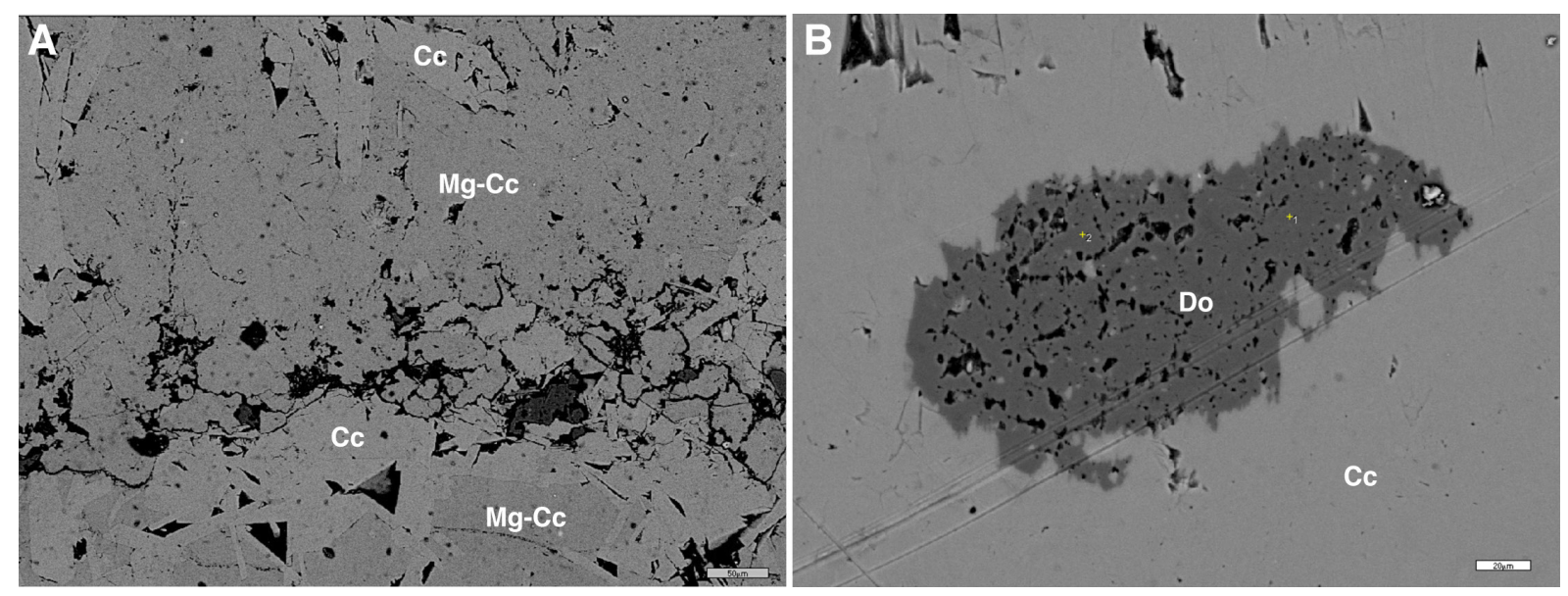

Fig. 5. Backscattered electron images from the stalactite from the Agios Georgios Cave: A) Pure calcite (Cc, light-coloured) coexisting with Mg-rich calcite (Mg-Cc, light grey). B) Dolomite (Do, grey) surrounded by pure calcite (Cc).

Table 1. Representative microanalyses of carbonate phases from the Agios Georgios stalactite (-: below detection limit; FeOt: total Fe as FeO)

\begin{tabular}{|l|c|c|c|c|c|c|}
\hline Sample No & AG1-3 & AG1-4 & AG1-5 & AG1-2 & AG1-1 & AG1-12 \\
\hline & Dolomite & Dolomite & Mg-Calcite & Mg-Calcite & Calcite & Calcite \\
\hline $\mathrm{FeO}^{\mathrm{t}}$ & 0.22 & 0.25 & - & 0.03 & 0.01 & - \\
\hline $\mathrm{MgO}$ & 20.87 & 19.22 & 2.1 & 4.56 & 0.14 & 0.06 \\
\hline $\mathrm{CaO}$ & 32.89 & 34.56 & 53.87 & 51.12 & 55.83 & 55.85 \\
\hline $\mathrm{Total}$ & 53.98 & 54.03 & 55.97 & 55.71 & 55.98 & \\
\hline \multicolumn{7}{|c|}{ Structural formulae on the basis of 2 O } \\
\hline $\mathrm{Fe}^{\mathrm{t}}$ & 0.006 & 0.006 & - & 0.001 & - & - \\
\hline $\mathrm{Mg}^{+}$ & 0.935 & 0.870 & 0.103 & 0.221 & 0.007 & 0.003 \\
\hline $\mathrm{Ca}^{2+}$ & 1.059 & 1.124 & 1.897 & 1.778 & 1.993 & 1.997 \\
\hline
\end{tabular}

many cases, it was observed that muscovite alters to a filamentous or tubular-like silicate, that EDX shows to be composed of $\mathrm{Al}$ and $\mathrm{Si}$ and we identify as


from the rims of the muscovite crystals (Fig. 7C). The halloysite-like crystals appear as both tubular (Figs. 7A, B and D) and platy forms, with the last forming commonly as pseudomorphic replacement of muscovite
(Figs. 7E and 8). Similar tubular halloysite has also been interpreted as a typical alteration product of micas from other studies (e.g. Esteoule-Choux \& Blanchet, 1987; Papoulis et al., 2004; 2009). Occurrence of platy halloysite is not unusual and it has been reported by previous authors (e.g. Noro, 1986; Papoulis et al., 2004; Joussein et al., 2005 and references therein). The extremely limited amount of 

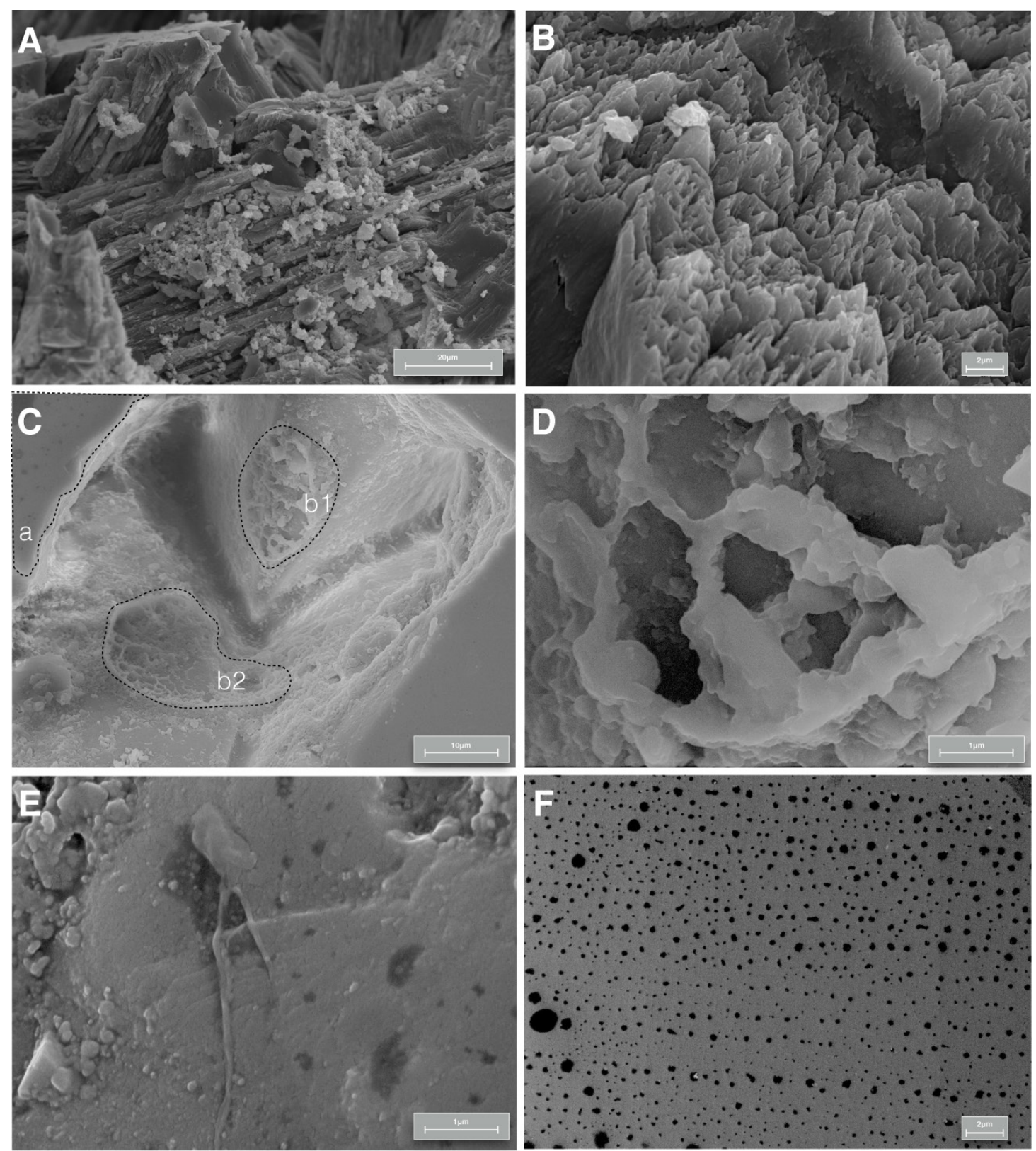

Fig. 6. Secondary electron images showing textures related to microbial activities in the stalactite from the Agios Georgios Cave: A) Microcrystalline calcite covering columnar calcites; B) Spiky calcite terminations on columnar crystals; C) Irregular features, which are interpreted to represent microbial boring on a calcite surface (a) and calcified net structures in calcite pockets ( $b 1$ and b2); D) Close-up image of the b1 structure from image $C$; E) Close-up image of microbial boring on a calcite surface; F) Linear distribution of calcite boring.

these clay minerals in the investigated speleothem did not allow us to employ other techniques (e.g. infrared spectroscopy or formamide intercalation) in order to verify if the platy crystals comprise halloysite or/ and kaolinite; hence the (co-)existence of typical platy kaolinite cannot be precluded. Figures $7 \mathrm{E}, 8 \mathrm{~A}$ and $8 \mathrm{~B}$ show platy crystals that we interpret to be halloysite, which have pseudomorphically replaced muscovite. Apparently, the platy form of the precursor mica controlled the crystal habit of the neoformed clay mineral.

Silica in this stalactite was identified with the aid of EDX and is associated with the presence of muscovite and halloysite, forming needle-like and blade-like euhedral quartz crystals or spherical aggregates of small clusters with anhedral shape (Figs. 7F and G). Spherical silica aggregates are observed with gibbsite crystals (also identified from their EDX spectra) with the typical spherical form (Fig. 7G). Gibbsite has developed on calcite substrate and it comprises the exclusive filling in several pores, (Fig. $7 \mathrm{H})$.

\section{XRD AND TEM RESULTS}

The carefully milled part of the speleothem sample was examined both with XRD and TEM. Besides pure and $\mathrm{Mg}$-rich calcite, $\mathrm{X}$-ray diffractograms indicated the presence of minor amounts of clay minerals; however their identification is difficult since their peaks are covered by the background scatter. Attempts to concentrate the insoluble residue that includes the clay minerals were unsuccessful and the collected amounts were negligible and insufficient for their identification. TEM was used in order to obtain more crystallographic information about the stalactite and its contents. In high resolution images, most of the carbonate grains are undeformed and show no defects. Pure calcite is by far the most abundant mineral, with 

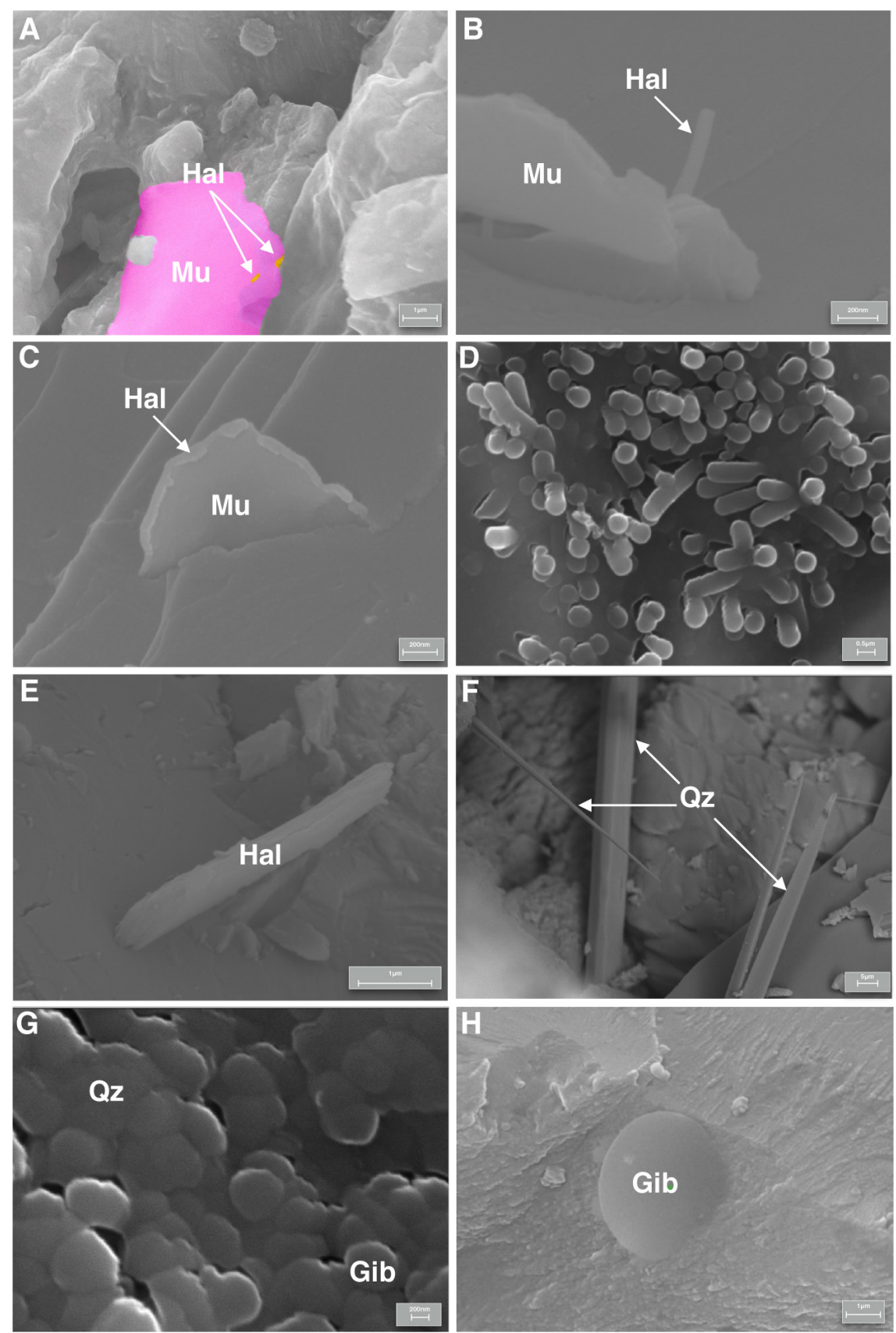

Fig. 7. Secondary electron images from fresh fractures with characteristics related to the formation of clay minerals from the stalactite of the Agios Georgios Cave: A) Pseudocolourised image of initial stage of tubular halloysite (Hal) formation after detrital muscovite (Mu); B) Development of a tube of halloysite on an anhedral, detrital muscovite $(\mathrm{Mu})$ entrapped in pores of calcite; $\mathrm{C}$ ) Initial stage of alteration of a muscovite $(\mathrm{Mu})$ rim to halloysite (Hal); D) Radially developed tubular halloysite crystals in pores of the stalactite; E) Platy halloysite-like mineral that has pseudomorpically replaced a detrital muscovite that is entrapped in a pore of calcite; F) Needle-like and blade-like quartz (Qz) crystals developed in a pore of the stalactite surrounded by calcite; G) Spherical quartz (Qz) and gibbsite (Gib) aggregates filling pores of the stalactite; $H$ ) Rounded gibbsite, which grows directly on calcite substrate, suggesting its in situ formation.

mostly its (006) faces being identified (after Zhang et al., 2010). The larger calcite particles are formed by multiple layers with syntaxial orientation or not, commonly showing a net fabric (Fig. 9A). Some areas with different structural modulations occur within the net fabric and are interpreted as $\mathrm{Mg}$-calcite (Figs. 9A and B). The minor presence of dolomite (whose presence has also been verified from microanalysis) cannot be excluded in some of regions of these images, as it is difficult to distinguish from Mg-calcite, due to the fact that their lattice spacing is similar. Fibrous crystals were commonly observed, too, and are identified as aragonite transforming to calcite (Fig. 9B); aragonite crystals expose more often their (111) or (121) faces during TEM observation. These aragonite crystals comprise most likely fibrous crystals that subsequently developed into columnar calcite, hence interpreting that the last grains form after coalescence of the initial aragonite crystals.

\section{ORIGIN OF CLAY MINERALS IN SPELEOTHEMS}

\section{Constrains and limitations}

Indisputable conclusions regarding the authigenic origin of silicate minerals is difficult to be drawn when visible evidence for any microbe activity is not obvious. Our hypothesis for the formation of clay minerals in the speleothems from Agios Georgios Cave at Kilkis is based on the detailed observation of their textural relationships. Tracing of microbial imprints on these minerals is achieved through coupled approaches in the studied speleothem. A detrital origin of the halloysite, quartz and gibbsite in the stalactite is not likely, due to the following reasons:

- Unlike the anhedral and deformed muscovite grains of detrital origin, halloysite, gibbsite and especially quartz show undisturbed and wellshaped crystals. It is unlikely the delicate, fibrous quartz crystals to maintain their shape if they had a clastic origin, although little is known regarding the transport of detritus in the cave drip system.

- Halloysite and gibbsite are closely associated with quartz (and muscovite) in the stalactite, hence a genetic relationship is recommended.

- Gibbsite and quartz grow directly on a calcite substrate, hence suggesting their authigenic origin.

Halloysite and gibbsite are well known to be weathering products, formed in tropic climates under highly oxidising conditions (e.g. in oxisols) where all the mobile elements are removed from the soil system (e.g. Herrman et al., 2007; Kleber et al., 2007). Even though the palaeoenviroment around the Agios Georgios Cave may have been tropical during the past formation of speleothems, such intense weathering processes are highly unlikely in a cave system and especially within a stalactite. In any case, this kind of process would have affected a large part of the cave, however no evidence (e.g. lateritisation) is observed for such an episode in the cave. We detected the formation 
Table 2. Representative microanalyses of detrital muscovite in pores from the Agios Georgios stalactite (-: below detection limit; $\mathrm{Fe}_{2} \mathrm{O}_{3}$ : total $\mathrm{Fe}$ as $\mathrm{Fe}_{2} \mathrm{O}_{3}$ ).

\begin{tabular}{|l|c|c|c|}
\hline \multicolumn{1}{|c|}{ Sample No } & AG1-7 & AG1-19 & AG1-21 \\
\hline $\mathrm{SiO}_{2}$ & 49.31 & 49.27 & 50.73 \\
\hline $\mathrm{TiO}_{2}$ & 0.62 & 0.47 & 0.26 \\
\hline $\mathrm{Al}_{2} \mathrm{O}_{3}$ & 30.58 & 30.41 & 28.59 \\
\hline $\mathrm{Fe}_{2} \mathrm{O}_{3}{ }^{\mathrm{t}}$ & 1.69 & 1.56 & 1.39 \\
\hline $\mathrm{MnO}$ & - & - & - \\
\hline $\mathrm{MgO}$ & 1.45 & 1.39 & 1.92 \\
\hline $\mathrm{CaO}$ & 0.65 & 0.54 & 2.22 \\
\hline $\mathrm{Na}{ }_{2} \mathrm{O}$ & 0.30 & 0.44 & 0.40 \\
\hline $\mathrm{K}_{2} \mathrm{O}$ & 10.42 & 10.44 & 9.81 \\
\hline $\mathrm{Total}$ & 95.02 & 94.52 & 95.32 \\
\hline & 6.562 & 6.589 & 6.729 \\
\hline $\mathrm{Si}$ & 1.438 & 1.411 & 1.271 \\
\hline $\mathrm{Al}{ }^{\mathrm{IV}}$ & 8.000 & 8.000 & 8.000 \\
\hline & 3.358 & 3.382 & 3.199 \\
\hline $\mathrm{Al}{ }^{\mathrm{vI}}$ & 0.062 & 0.047 & 0.026 \\
\hline $\mathrm{Ti}$ & 0.169 & 0.157 & 0.139 \\
\hline $\mathrm{Fe}$ & - & - & - \\
\hline $\mathrm{Mn}$ & 0.288 & 0.277 & 0.380 \\
\hline $\mathrm{Mg}$ & 0.093 & 0.077 & 0.316 \\
\hline $\mathrm{Ca}$ & 0.077 & 0.114 & 0.103 \\
\hline $\mathrm{Na}$ & 1.769 & 1.781 & 1.660 \\
\hline $\mathrm{K}$ & 13.816 & 13.836 & 13.822 \\
\hline
\end{tabular}

of halloysite and gibbsite at random sites in all growth phases of the stalactite, with the alteration processes to be restricted in spot areas within pores, not affecting the whole calcite growth laminae. Such randomly observed alteration phenomena favour evolution affected by microbial activity (Banfield et al., 1999).

Strong indications for the involvement of microbial activities in the formation of minerals in the stalactite are mentioned above. The existence of spiky and bored calcite provides evidence for the implication of microbial etching. In addition to this, microcrystalline calcite covering the spiky fabric, assumes that most probably a biofilm, which mediated the formation of the spiky calcite, provided the template on which the micrite and minimicrite precipitated (Jones, 2011). Thus, this microcrystalline material comprises texturally, the sparmicritic calcite (after Kahle, 1977), a term describing exclusively microbially precipitated calcite.

\section{Formation of microbially induced Mg-rich carbonates}

Recent studies have demonstrated that microorganisms play a significant role in the formation of Mg-bearing carbonate minerals at lowtemperatures. Several authors suggest the direct or indirect implication of bacterial metabolic processes, as well as their surfaces and their extra-cellular polysaccharides (EPS) to the formation of these carbonates (Vasconcelos et al., 1995; Vasconcelos \& McKenzie, 1997; Warthmann et al., 2000; Van
Lith et al., 2003; Moreira et al., 2004; Roberts et al., 2004; Wright \& Wacey, 2005, Sánchez-Román et al., 2008, 2011; Bontognali et al., 2014). Different types of microbes (sulphate-reducing, halophilic, methanogenic bacteria) have been shown to naturally and experimentally produce various Mg-rich carbonate minerals, in fresh and saline waters, with aerobic or anaerobic respirations. Although the exact role of microbes in our stalactite is uncertain, we propose that microbes are capable of modifying the physicochemical parameters of the microenvironment in their immediate vicinity in order to facilitate the precipitation of mineral phases which are either undersaturated or kinetically inhibited at these conditions. In addition to this, bacteria can serve as nuclei for carbonate mineral precipitation by adsorbing $\mathrm{Ca}, \mathrm{Mg}$ and other metallic cations onto their cell surface (membranes, walls and extracellular polymeric substances; Beveridge \& Fyfe, 1985; Van Lith et al., 2003; Bontognali et al., 2008). We suggest that the local formation of Mg-rich calcite (and dolomite) observed under TEM is evidence for microbial activity in the stalactite from Agios Georgios Cave. In our model, microbes modified the local microenvironment by shifting the $\mathrm{pH}$ to alkaline values, hence promoting local supersaturation conditions around them and formation of Mg-rich carbonates. However, the exact species of the bacteria inferred to have affected the formation of Mg-rich calcite are not known. There is no evidence for the existence of sulphate-reducing or methanogenic bacteria in the investigated stalactite and the cave conditions are highly unfavourable for the occurrence of halophile microorganisms. The microorganisms that involved in the formation of $\mathrm{Mg}$ rich carbonate minerals in the cave may belong to species whose implication in the formation of such phases has never been studied before. However, the determination of these species is beyond the scope of this study.

\section{Implications for microbial muscovite dissolution}

Assuming microbial activity is responsible for muscovite dissolution, we offer possible scenarios that could result in in-situ formed halloysite, gibbsite and quartz in the cave environment within the stalactite. A reaction that describes the formation of halloysite from muscovite, which is illustrated in Figures 7 and 8 , may be:

$$
\begin{aligned}
& 2 \mathrm{KAl}_{2}\left(\mathrm{AlSi}_{3} \mathrm{O}_{10}\right)(\mathrm{OH})_{2}+3 \mathrm{H}_{2} \mathrm{O}+2 \mathrm{H}^{+}= \\
& \begin{array}{c}
\text { Muscovite } \\
=3 \mathrm{Al}_{2} \mathrm{Si}_{2} \mathrm{O}_{5}(\mathrm{OH})_{4}+2 \mathrm{~K}^{+} \\
\text {Halloysite- } 7 \AA
\end{array}
\end{aligned}
$$

As it was mentioned above there is an uncertainty for the exclusive occurrence or coexistence of platy kaolinite in the sample, hence kaolinite may coexist with halloysite, formed also by the above reaction. These two minerals can also be structurally related to each other via solid-state transformations (Jeong, 1998; Papoulis et al., 2004; Churchman et al., 2010). Apart from low $\mathrm{pH}$, kaolinite formation is generally favoured from halloysite at higher alumina and lower 

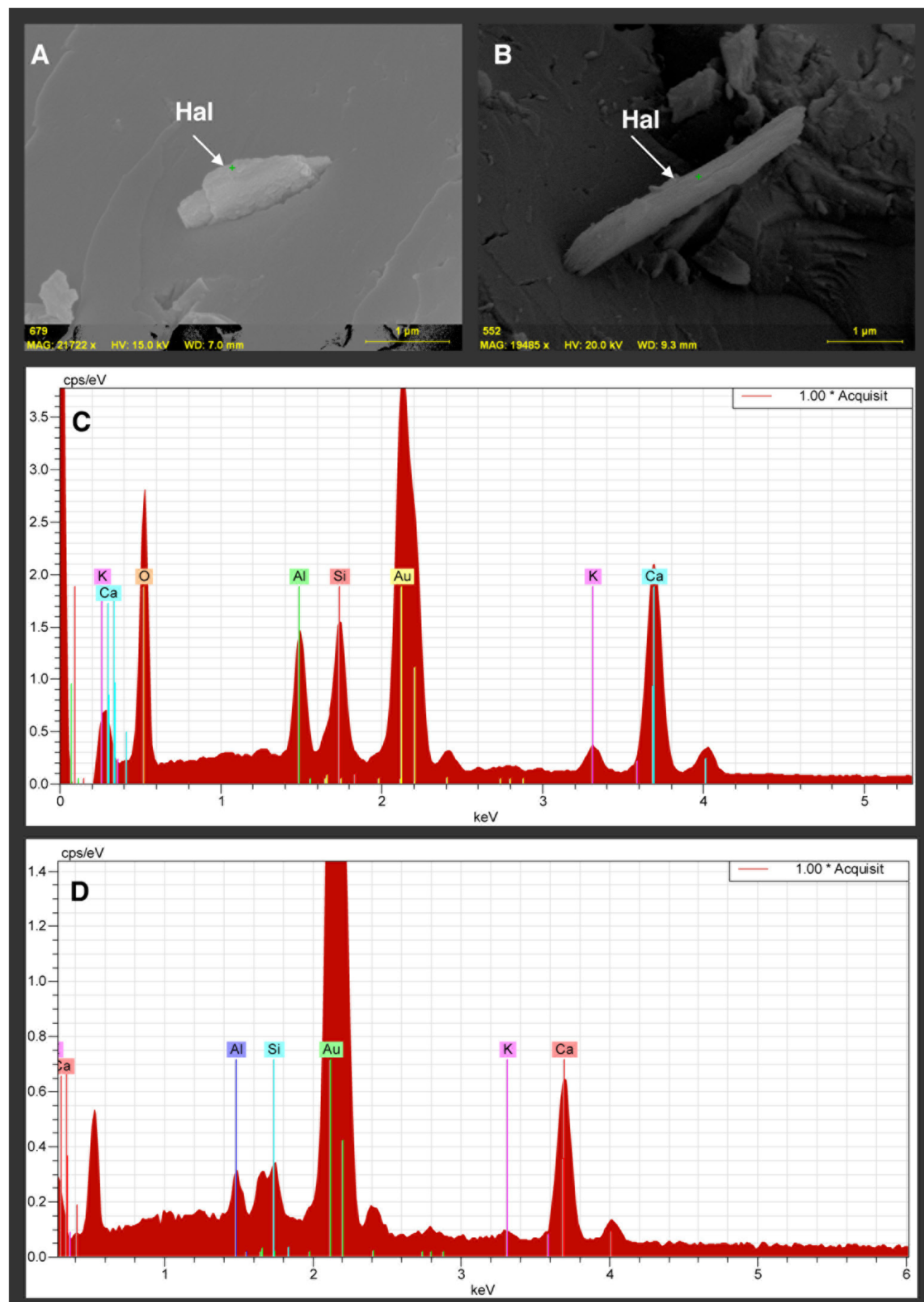

Fig. 8. A-B) Secondary electron images of platy halloysite-like minerals which have been pseudomorphically formed after detrital muscovites; C-D) EDX spectra: Spectrum C corresponds to image A, and spectrum D to image B respectively. We interpret the short $K$ peak in the second image indicates the existence of relic muscovite precursor. Ca peaks are due to interaction of the beam with the surrounding calcite while Au is due to coating. 



Fig. 9. High resolution TEM images from the Agios Georgios stalactite: A) Calcite (Cc) grains forming a net fabric with patches of lighter areas with different lattice dense, indicating the presence of $\mathrm{Mg}$-calcite $(\mathrm{Mg}-\mathrm{Cc})$ as a result of microbial activity; B) A fibrous carbonate crystal showing the transformation of aragonite (Arg) to the darker area comprising calcite; light, Mg-calcite (Mg-Cc) patchy areas are present, too.

silica activities, as well as at drier conditions (Joussein et al., 2005; Churchman et al., 2010). The flocculation of silica, as well as its coexistence with gibbsite that indicate high water flow (see below) suggest that the platy silicate mineral is more probably halloysite although coexistence with kaolinite is not precluded. In any case, the conditions of the formation of these clay minerals in the microenvironment of the stalactite pores are not strongly different. Obviously, the naturally alkaline dripping water in caves is not suitable for this low temperature alteration that requires the presence of acidic conditions. This is the main basis for suggesting a microbial-related origin for the silicates. It is well accepted, that many microorganisms including actinomycetes, bacillus species (e.g. Bacillus mucilaginosus), fungal species, etc., which are found mainly in the rhizosphere, have the capability to dissolve silicate minerals, in order to uptake the prior non exchangeable $\mathrm{K}^{+}$(Basak \& Biswas 2009). It has been shown that deterioration of potassium silicate minerals is promoted by organic compounds such as acetates, citrates and oxalates, produced by these microorganisms (Argelis et al., 1993; Bennett et al., 1998; Sheng, 2003). Furthermore, Bennett et al. (2001) reported that certain microorganisms can produce various organic ligands during their metabolic activities, such as metabolic byproducts, extracellular enzymes, chelates, as well as simple and complex organic acids, which catalyse the dissolution of potassium silicate minerals, by decreasing the $\mathrm{pH}$ of the environment. Nevertheless, these reports are not conclusive to determine whether these potassium solubilising microorganisms (PSM) may exist in cave environments. It is broadly known that caves have relatively constant, low temperature, high relative humidity levels and low quantities of organic nutrients, presenting seemingly an environment far from ideal for the vast majority of the microorganisms. Nevertheless, Groth \& SaizJimenez (1999) have suggested that actinomycetes are abundant in caves and their growth is favoured by the association of low temperature and high relative humidity. Moreover, algae and cyanobacteria have been commonly found in caves (e.g., Banfield et al., 1999; Roldán \& Hernández-Mariné, 2009; Lamprinou et al., 2015), whereas Laiz et al., (2000) sampled many bacterial isolates from speleothems, and more specifically from stalactites, which include various species of Streptomyces, Bacillus, Nocardiopsis, Rhodococcus, Agromyces, Arthrobacter, Amycolatopsis, Brevibacillus, Micrococcus, Staphylococcus, Paenibacillus and Variovorax. Therefore, in the microenvironments within stalactites, the metabolic activities of such microorganisms may have locally lowered the $\mathrm{pH}$ enough to promote the alteration of muscovite in the Agios Georgios stalactite.

\section{Implications for microbial clay mediation}

In certain places within the stalactite layers we observed what we interpret to be the presence of (i) halloysite, (ii) halloysite + silica, (iii) gibbsite + silica, and (iv) gibbsite (Fig. 7). The observed silica forms include needles or blade-like crystals of quartz, as well as spheroidal aggregates of nearly amorphous 
$\mathrm{SiO}_{2}$; in most of the cases, all of them are related to muscovite alteration. Tubular bio-halloysite derives from clay bubbles and its formation has been reported in microbial films and on the surface of bacillus taxa bacteria (Tazaki, 2005); sulphurreducing bacteria are mostly reported as catalysts for halloysite formation in soils (e.g. Herrmann et al., 2007), however the conditions in Agios Georgios Cave seem not to favour the presence of sulphurreducing bacteria. Nevertheless, Tazaki (2005) suggested that these clay bubbles can also form by microbial inflation from algae or cyanobacteria (which is more possible to have taken place in our case), via $\mathrm{O}_{2}, \mathrm{CO}_{2}$ or $\mathrm{H}_{2} \mathrm{~S}$ degassing and hence forming eventually immature kaolin clay that forms the hollow structure of halloysite.

In this work, we suggest that reaction (1) explains well the presence of halloysite in certain pores, with the aid of PSM (Fig. 10). However, to explain the halloysite + quartz assemblage we must encounter the reaction:

$$
\begin{aligned}
& \mathrm{Al}_{2} \mathrm{Si}_{2} \mathrm{O}_{5}(\mathrm{OH})_{4}+6 \mathrm{H}^{+}=2 \mathrm{Al}^{3+}+2 \mathrm{H}_{4} \mathrm{SiO}_{4}+\mathrm{H}_{2} \mathrm{O}
\end{aligned}
$$

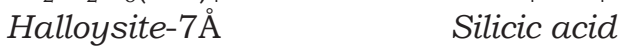

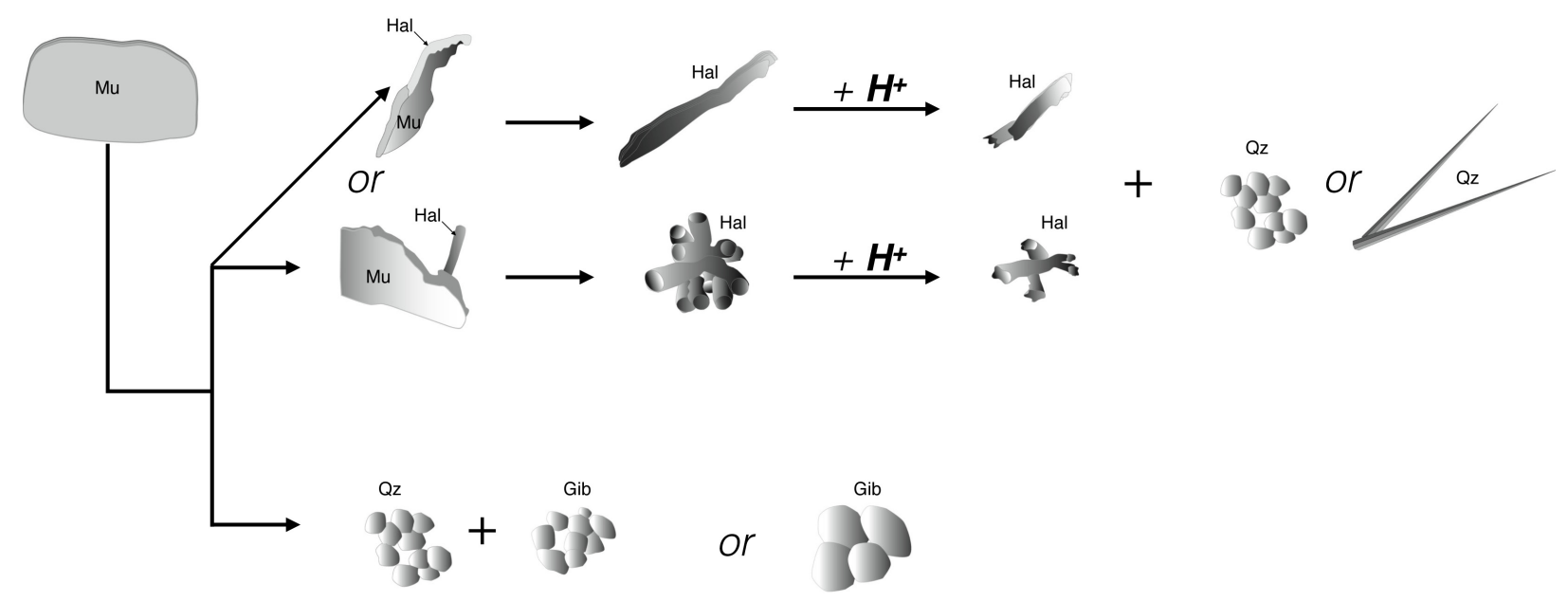

Fig. 10. Simplified illustration of the alteration process of muscovite to halloysite and subsequently to silica, as well as to gibbsite and silica; the illustrated crystal relationships are based on observations under SEM.

The Al cations produced from this reaction may have leached away and with increasing silica activity the various forms of silica have been formed with or without remnants of excess halloysite (Fig. 10). Experimental results have shown that, under acidic conditions, dissolution of halloysite is initiated on the inner surface of nanotubes, leading to the formation of amorphous spheroidal nanoparticles of $\mathrm{SiO}_{2}$ (White et al., 2012), in line with our observations in the Agios Georgios porous system of the stalactite.

The implication of biogenic factors on the formation of gibbsite in bauxite deposits has been confirmed (Laskou \& Economou-Eliopoulos, 2007), however, the precise role of microorganisms in its formation has not been fully unraveled. Nevertheless, the Bacillus taxa bacteria can flocculate Fe-oxides, alumina and calcite through the excretion of polysaccharides (Maurice et al., 2001; Li et al., 2004), hence providing the necessary Al for gibbsite formation. Under oxic conditions the necessary Al for gibbsite formation may also derive as a byproduct, resulting from other microbial processes such as Ca uptake (Anand et al., 1996).

Precipitation of gibbsite is generally favoured from other polymorphs due to its faster crystallisation. The $\mathrm{Al}^{3+}$ ions leached from reaction (2) may have been deposited at pores forming the observed monomineralic gibbsite (Fig. 10). Direct formation of gibbsite from high leaching rates of muscovite is reported at mildly acidic to mildly alkaline conditions, low temperature, high water percolation, slow evaporation and when the dissolved silica is not high (Essington, 2005; Herrman et al., 2007; Watanabe et al., 2010) and may be described by the reaction:

$$
\begin{aligned}
& \mathrm{KAl}_{2}\left(\mathrm{AlSi}_{3} \mathrm{O}_{10}\right)(\mathrm{OH})_{2}+\mathrm{H}^{+}+ \\
& \text {Muscovite } 9 \mathrm{H}_{2} \mathrm{O}= \\
&=\mathrm{K}^{+}+3 \mathrm{H}_{4} \mathrm{SiO}_{4}+3 \mathrm{Al}(\mathrm{OH})_{3} \\
& \text { Gibbsite }
\end{aligned}
$$

It is possible that this reaction was favoured for the decomposition of the detrital muscovite when the pores had larger space allowing unobstructed water flow and may explain the coexistence of gibbsite and silica under variable silica activities (Fig. 10). Nevertheless, experimental results have shown that gibbsite can also form from dissolution of halloysite, at alkaline conditions (White et al., 2012). Such a scenario seems less likely, as it is well established that mild acidic conditions were prevailing in the pores of the stalactite (unlike the carbonate basement with the formation of Mg-rich calcite) and furthermore gibbsite was never found in direct association with halloysite.

\section{CONCLUSIONS}

A new, seemingly unexpected, microenvironment for the formation of authigenic halloysite and gibbsite is described in the pore system of a stalactite in Agios Georgios Cave. We interpret that the formation of platy and tubular halloysite (and/or kaolinite) is unambiguously related to the dissolution of detrital muscovite entrapped in the pores of the stalactite. Acidic conditions were established locally by PSM (such as actinomycates, algae or cyanobacteria) by their metabolic excreta. Further dissolution of halloysite to form silica minerals is promoted by these acidic conditions. We also interpret that gibbsite 
comprises a product of extreme muscovite leaching maybe at larger pores with high and unhindered water flow at the same mildly acidic conditions. It is probable that an antagonistic relationship exists between microbe colonies, in the main carbonate basement, whose metabolic activities induced an alkaline microenvironment for the crystallisation of Mg-rich carbonates, with those microbes which created an acidic microenvironment in the pores of the stalactite, inducing the breakdown of muscovite and the formation of halloysite and gibbsite.

\section{ACKNOWLEDGEMENTS}

The authors are grateful for the critical comments of Professor N. Güven and two anonymous reviewers that largely improved the manuscript. We greatly appreciate the support of Ephoreia of PalaeoanthropologySpeleology of North Greece for providing license to investigate the cave.

\section{REFERENCES}

Anand T.P., Edward J.K.P. \& Ayyakkannu K., 1996 - Monitoring of a shrimp culture system with special reference to vibrio and fungi. Indian Journal of Marine Sciences, 25: 253-258.

Antonelou A., 2007 - Study of speleothems from Agios Geogios Cave, Kilkis prefecture: Investigation of paleoclimatic environmental conditions using stable isotopes of $C$ and $O$. Unpublished MS Thesis, University of Patras, $183 \mathrm{p}$.

Antonelou A., Tsikouras B., Papoulis D. \& Hatzipanagiotou K., 2010 - Investigation of the formation of speleothems in the Agios Georgios Cave (N. Greece). Bulletin of Geological Society of Greece, 43: 876-885.

Argelis D.T., Gonzala D.A., Vizcaino C. \& Gartia M.T., 1993 - Biochemical mechanism of stone alteration carried out by filamentous fungi living in monuments. Biogeochemistry, 19: 129-147.

Banfield J.F., Barker W.W., Welch S.A. \& Taunton A., 1999 - Biological impact on mineral dissolution: application of the lichen model to understanding mineral weathering in the rhizosphere. Proceedings of the National Academy of Sciences, 96: 3404-3411.

http://dx.doi.org/10.1073/pnas.96.7.3404

Basak B.B. \& Biswas D.R., 2009 - Influence of potassium solubilizing microorganism (Bacillus mucilaginosus) and waste mica on potassium uptake dynamics by sudan grass (Sorghum vulgare Pers.) grown under two Alfisols. Plant and Soil, 317: 235-255.

http://dx.doi.org/10.1007/s11104-008-9805-Z

Baskar S., Baskar R., Mauclaire L. \& McKenzie J.A., 2005 - Role of microbial community in stalctite formation, Sahastradhara caves, Dehradun, India. Current Science, 88: 1305-1308.

Baskar S., Baskar R., Mauclaire L. \& McKenzie J.A., 2006 - Microbially induced calcite precipitation by culture experiments - possible origin for stalactites in Sahastradhara, Dehradun, India. Current Science, 90: 58-64.

Bennett P.C., Choi W.J. \& Rogera J.R., 1998 - Microbial destruction of feldspars. Mineral Management, 62A: $149-150$.

Bennett P.C., Rogers J.R. \& Choi W.J., 2001 Silicates, silicate weathering and microbial ecology. Geomicrobiology Journal, 18: 3-19.

http://dx.doi.org/10.1080/01490450151079734
Beveridge T.J. \& Fyfe W.S., 1985 - Metal fixation by bacterial cell walls. Canadian Journal of Earth Sciences, 22: 1892-1898.

http://dx.doi.org/10.1139/e85-204

Bontognali T.R.R., Vasconcelos C., Warthmann R., Dupraz C., Bernasconi S.M. \& McKenzie J.A., 2008 Microbes produce nanobacteria-like structures, avoiding cell entombment. Geology, 36: 663-666. http://dx.doi.org/10.1130/G24755A.1

Broughton P.L., 1983 - Environmental implications of competitive growth fabrics in stalactitic carbonate. International Journal of Speleology, 13: 31-41. http://dx.doi.org/10.5038/1827-806X.13.1.3

Churchman G.J., Pontifex I.R. \& McClure S.G., 2010 Factors influencing the formation and characteristics of halloysites or kaolinites in granitic and tuffaceous saprolites in Hong Kong. Clays and Clay Minerals, 58: $220-237$.

http://dx.doi.org/10.1346/CCMN.2010.0580207

Dotsika E., Psomiadis D., Zanchetta G., Spyropoulos N., Leone G., Tzavidopoulos I. \& Poutoukis D., 2010 - Pleistocene palaeoclimatic evolution from Agios Georgios Cave speleothem (Kilkis, N. Greece). Bulletin of the Geological Society of Greece, 43: 886-895.

Essington M.E., 2005 - Soil and water chemistry: an integrative approach. Taylor and Francis e-Library, 534 p.

Folk R.L., 1974 - The natural history of crystalline calcium carbonate: effect of magnesium content and salinity. Journal of Sedimentary Petrology, 44: 40-53.

Folk R.L., Chafetz H.S. \& Tiezzi P.A., 1985 - Bizarre forms of depositional and diagnetic calcite in hot-spring travertines, central Italy. In: Schneidermann N. \& Harris P.M. (Eds.), Carbonate cements: SEPM. Special Publication, 36: 349-369.

http://dx.doi.org/10.2110/pec.85.36.0349

Frisia S., Borsato A., Fairchild I. \& Mcdermott F., 2000 - Calcite fabrics, growth mechanisms, and environment of formation in speleothems from the Italian Alps and southwestern Ireland. Journal of Sedimentary Research, 70: 1183-1196.

http://dx.doi.org/10.1306/022900701183

Groth I. \& Saiz-Jimenez C., 1999 - Actinomycetes in hypogean environments. Geomicrobiology Journal, 16: 1-8. http://dx.doi.org/10.1080/014904599270703

Herrmann L., Anongrak N., Zarei M., Schuler U. \& Spohrer K., 2007 - Factors and processes of gibbsite formation in Northern Thailand. Catena, 71: 279-291. http://dx.doi.org/10.1016/j.catena.2007.01.007

Hill C.A. \& Forti P., 1997 - Cave minerals of the world. $\left(2^{\text {nd }}\right.$ ed). National Speleological Society, Huntsville, 463 p.

Ifandi E., Tsikouras B. \& Hatzipanagiotou K., 2013 - Contribution to the evolution of the Perama Cave (Ioannina, NW Greece). Bulletin of the Geological Society of Greece, 47: 255-263.

Jeong G.Y., 1998 - Formation of vermicular kaolinite from halloysite aggregates in the weathering of plagioclase. Clays and Clay Minerals, 46: 270-279. http://dx.doi.org/10.1346/CCMN.1998.0460306

Jones B., 2010 - Microbes in caves: agents of calcite corrosion and precipitation. In: Pedley H.M. \& Rogerson M. (Eds.), Tufas and speleothems: Unravelling the microbial and physical controls. Geological Society, London, Special Publications, $7 \mathrm{p}$. http://dx.doi.org/10.1144/sp336.2

Jones B., 2011 - Stalactite growth mediated by biofilms: Example from Nani Cave, Cayman Brac, British West Indies. Journal of Sedimentary Research, 81: 322-338. http://dx.doi.org/10.2110/jsr.2011.28

Joussein E., Petit S., Churchman J., Theng B., Righi D. \& Delvaux B., 2005 - Halloysite clay minerals - A review. Clay Minerals, 40: 383-426. 
Kahle C.F., 1977 - Origin of subaerial Holocene calcareous crust: Role of algae, fungi, and sparmicritisation. Sedimentology, 24: 413-435.

Kaufmann G., Kockel F. \& Mollat H., 1976 - Notes on the stratigraphic and paleogeographic position of the Svoula Formation in the Innermost Zone of the Hellenides (northern Greece). Bulletin de la Societe Geologique de France, 18: 225-230.

http://dx.doi.org/10.2113/gssgfbull.S7-XVIII.2.225

Kendall A.C. \& Broughton P.L., 1978 - Origin of fabrics in speleothems composed of columnar calcite crystals. Journal of Sedimentary Petrology, 48: 519-538.

Kleber M., Sollins P. \& Sutton R., 2007 - A conceptual model of organo-mineral interactions in soils: selfassembly of organic molecular fragments into zonal structures on mineral surfaces. Biogeochemistry, 85: 9-24. http://dx.doi.org/10.1007/s10533-007-9103-5

Kockel F. \& Ioannides K., 1979 - Geological Map of Greece, Kilkis sheet. Scale 1:50.000, Institute of Geology and Mineral Exploration, Greece.

Laiz L., Groth I., Schumann P., Zezza F., Felske A., Hermosin B. \& Saiz-Jimenez C., 2000 - Microbiology of the stalactites from Grotta dei Cervi, Porto Badisco, Italy. International Microbiology, 3: 25-30.

Lamprinou V., Tryfinopoulou K., Velonakis E.M., Vatopoulos A., Antonopoulou S., Fragopoulou E., Pantazidou P. \& Economou-Amilli A., 2015 - Cave Cyanobacteria showing antibacterial activity. International Journal of Speleology, 44: 231-238.

http://dx.doi.org/10.5038/1827-806X.44.3.2

Laskou M. \& Economou-Eliopoulos M., 2007 - The role of microorganisms on the mineralogical and geochemical characteristics of the Parnassos- Ghiona bauxite deposits, Greece. Journal of Geochemical Exploration, 93: $67-77$. http://dx.doi.org/10.1016/i.gexplo.2006.08.014

Li Y.L., Vali H., Sears S.K., Yang J., Deng B.L. \& Zhang C.L., 2004 - Iron reduction and alteration of nontronite NAu-2 by a sulfate-reducing bacterium. Geochimica et Cosmochimica Acta, 68: 3251-3260.

http://dx.doi.org/10.1016/j.gca.2004.03.004

Makridis V., Tsoukala E., Vlachos E., Tsekoura K., van Logchem W. \& Mol D., 2013 - Agios Georgios Cave, Kilkis: 50 years of history, 30,000 years of prehistory. Deposits Magazine, 34: 30-36.

Maurice P.A., Vierkorn M.A., Hersman L.E. \& Fulghum J.E., 2001 - Dissolution of well- and poorly ordered kaolinites by an aerobic bacterium. Chemical Geology, 180: 81-97.

http://dx.doi.org/10.1016/S0009-2541(01)00307-2

Moreira N.F, Walter L.M., Vasconcelos C., McKenzie J.A. \& McCall J.P., 2004 - Role of sulfide oxidation in dolomitization: sediment and pore-water geochemistry of a modern hypersaline lagoon system. Geology, 32: 701-704. http://dx.doi.org/10.1130/G20353.1

Mulec J., Kosi G. \& Vrhovsek D., 2007 - Algae promote growth of stalagmites and stalactites in karst caves (Skocjanske jame, Slovenia). Carbonates and Evaporites, 22: 6-9.

http://dx.doi.org/10.1007/BF03175841

Noro H., 1986 - Hexagonal platy halloysite in an altered tuff bed, Komaki City, Aichi prefecture, central Japan. Clay Minerals, 21: 401-415.

http://dx.doi.org/10.1180/claymin.1986.021.3.11

Northup D.E. \& Lavoie K., 2001 - Geomicrobiology of caves: A review. Geomicrobiology Journal, 18: 199-222. http://dx.doi.org/10.1080/01490450152467750
Onac B.P. \& Forti P., 2011 - Minerogenetic mechanisms occurring in the cave environment: an overview. International Journal of Speleology, 40 (2): 79-98 http://dx.doi.org/10.5038/1827-806X.40.2.1

Pacton M., Breitenbach S.F.M., Lechleitner F.A., Vaks A., Rollion-Bard C., Gutareva O.S., Osintcev A.V. \& Vasconcelos C., 2013 - The role of microorganisms in the formation of a stalactite in Botovskaya Cave, Siberia - Paleoenvironmental Implications. Biogeosciences, 10: 6115-6130. http://dx.doi.org/10.5194/bg-10-6115-2013

Papoulis D., Tsolis-Katagas P. \& Katagas C., 2004 Progressive stages in the formation of kaolin minerals of different morphologies in the weathering of plagioclase. Clays and Clay Minerals, 52: 275-286. http://dx.doi.org/10.1346/CCMN.2004.0520303

Papoulis D., Tsolis-Katagas P., Kalampounias A.G. \& Tsikouras B., 2009 - Progressive formation of halloysite from the hydrothermal alteration of biotite and the formation mechanisms of anatase in altered volcanic rocks from Limnos Island, northeast Aegean Sea, Greece. Clays and Clay Minerals, 57: 566-577. http:/ /dx.doi.org/10.1346/CCMN.2009.0570505

Polyak V.J. \& Güven N., 2000 - Clays in caves of the Guadalupe Mountains, New Mexico. Journal of Cave and Karst Studies, 62: 120-126.

Polyak V.J. \& Güven N., 2004 - Silicates in carbonate speleothems, Guadalupe Mountains, New Mexico, U.S.A. In: Sasowsky I.D. \& Mylroie J. (Eds), Studies of cave sediments, physical and chemical records of paleoclimate. Springer, $303 \mathrm{p}$.

Roberts J., Bennett P.C., González L.A., Macpherson G.L. \& Miliken K.L., 2004 - Microbial precipitation of dolomite in methanogenic groundwater. Geology, 32: 277-280. http://dx.doi.org/10.1130/G20246.2

Roldan M. \& Hernández-Mariné M., 2009 - Exploring the secrets of the three-dimensional architecture of phototrophic biofilms in caves. International Journal of Speleology, 38 (1): 41-53. http://dx.doi.org/10.5038/1827-806X.38.1.5

Rusznyák A., Akob M.D., Nietzsche S., Eusterhues K., Uwe Totsche K., Neu R.T., Frosch T., Popp J., Keiner R., Geletneky J., Katzschmann L., Schulze E-D., \& Küsel K., 2012 - Calcite biomineralization by bacterial isolates from the recently discovered pristine Karstic Herrenberg Cave. Applied and Environmental Microbiology, 78: 1157-1167.

http://dx.doi.org/10.1128/AEM.06568-11

Sánchez-Román M., Romanek C.S., Fernández-Remolar D., Sánchez-Navas A., McKenzie J.A., Amils-Pibernat R. \& Vasconcelos C., 2011 - Aerobic biomineralization of Mg-rich carbonates: Implications for natural environments. Chemical Geology, 281: 143-150.

Sanchez-Roman M., Vasconcelos C., Schmid T., Dittrich M., McKenzie J.A., Zenobi R. \& Rivadeneyra M.A., 2008 - Aerobic microbial dolomite at the nanometer scale: implications for the geologic record. Geology, 36: 879-882.

http://dx.doi.org/10.1130/G25013A.1

Sheng X.F., Xia J.J. \& Chen J., 2003 - Mutagenesis of the Bacillus edaphicaus strain NBT and its effect on growth of chili and cotton. Agricultural Sciences in China, 2: 40-41.

Tazaki K., 2005 - Microbial formation of a halloysite-like mineral. Clays and Clay Minerals, 53: 224-233. http://dx.doi.org/10.1346/CCMN.2005.0530303

Tsoukala E.S., 1992 - The Pleistocene large mammals from the Agios Georgios Cave, Kilkis (Macedonia, N. Greece). Geobios, 25:415-433. http://dx.doi.org/10.1016/0016-6995(92)80015-6 
van Lith Y., Warthmann R., Vasconcelos C. \& McKenzie J.A., 2003 - Microbial fossilization in carbonate sediments: A result of the bacterial surface involvement in dolomite precipitation. Sedimentology, 50: 237-245. http://dx.doi.org/10.1046/j.1365-3091.2003.00550.x Vasconcelos C., McKenzie J.A., Bernasconi S., Grujic D. \& Tien A.J., 1995 -Microbial mediation as a possible mechanism for natural dolomite formation at low temperatures. Nature, 377: 220-222.

http://dx.doi.org/10.1038/377220a0

Vasconcelos C. \& McKenzie J.A., 1997 - Microbial mediation of modern dolomite precipitation and diagenesis under anoxic conditions (Lagoa Vermelha, Rio de Janeiro, Brazil). Journal of Sedimentary Research, 67: 378-390.

Warthmann R., van Lith Y., Vasconcelos C., McKenzie J.A. \& Karpoff A.M., 2000 - Bacterially induced dolomite precipitation in anoxic culture experiments. Geology, 28: 1091-1094.

http://dx.doi.org/10.1130/0091-7613(2000)28 $<$ 1091:BIDPIA $>2.0 . \mathrm{CO} ; 2$
Watanabe T., Funakawa S. \& Kosaki T., 2010 Distribution and formation conditions of gibbsite in the upland soils of humid Asia: Japan, Thailand and Indonesia. In: Proceeding of the $19^{\text {th }}$ World Congress of Soil Science. Soil Solutions for a Changing World. Brisbane, $103 \mathrm{p}$.

White D.R., Bavykin V.D. \& Walsh C.F., 2012 - The stability of halloysite nanotubes in acidic and alkaline aqueous suspensions. Nanotechnology, 23: 065705. http://dx.doi.org/10.1088/0957-4484/23/6/065705

Wright D.T. \& Wacey D., 2005 - Precipitation of dolomite using sulphate-reducing bacteria from the Coorong region, south Australia: Significance and implications. Sedimentology, 52: 987-1008.

http://dx.doi.org/10.1111/j.1365-3091.2005.00732.x

Zhang F., Xu H., Konishi H. \& Roden E.E., $2010-A$ relationship between $d 104$ value and composition in the calcite-disordered dolomite solid-solution series. American Mineralogist, 95: 1650-1656. http://dx.doi.org/10.2138/am.2010.3414 